\title{
Nos diagramas do texto, sombras da violência no "Verão" de Porto Alegre
}

\author{
In the diagrams of the text, shades of the violence at "Verão" in Porto Alegre
}

\author{
Carlos Augusto Magalhães \\ Universidade do Estado da Bahia - Salvador - Bahia - Brasil
}

A

Resumo: Este artigo visa apresentar uma leitura da violência nos contos "Verão" e "A aventura prático-intelectual do Sr. Alexandre Costa" do livro Os lados do círculo. Nessa leitura, o objetivo é observar as experiências com os espaços e seus processos de expansão em Porto Alegre, pensando-se nas décadas de 50, 60 e 70, em comparação com as experiências no século XXI. Com sua economia e ação concentrada, o conto torna-se um gênero adequado para essas e outras leituras, conforme alguns comentários do autor das narrativas em estudo. Ambos os contos analisam a violência urbana: o homicídio de pessoas moradoras de rua por um serial killer em "A aventura..." e do empresário Wagner Henrique, resultado de embates entre ele e a população da favela da Vila Cruzeiro no conto "Verão".

Palavras-chave: Literatura contemporânea; Amilcar Bettega Barbosa; Os lados do círculo; Conto; Violência

\begin{abstract}
This article aims to present a reading of violence in Amilcar Bettega Barbosa's short stories "Verão" and "A aventura prático-intelectual do Sr. Alexandre Costa" from his book Os lados do círculo. In this reading, the objective is to observe the experiences with the spaces and their processes of expansion in Porto Alegre in the 1950s, 1960s, and 1970s in comparison with the experiences in the 21 st century. With its economy and concentrated action, the short story becomes a suitable genre for these and others readings, according to some comments by the author himself. Both short stories analyze urban violence: the homicide of homeless people by a serial killer in "A Aventura" and that of the businessman Wagner Henrique, resulting from clashes between him and the population of the shantytown Vila Cruzeiro in the short story "Verão".
\end{abstract}

Keywords: Contemporary literature; Amilcar Bettega Barbosa; Os lados do círculo; Short story; Violence

As caminhadas diárias [...] são muito benéficas. [...] Lima Barreto também dizia que ao caminhar pensava melhor, Baudelaire foi um grande flâneur.

AMILCAR BETTEGA BARBOSA

A dimensão do conto e a particularização de seu conflito fizeramno distinguir-se da outra grande forma narrativa, o romance.

FÁBIO LUCAS 


\section{Nos entremeios da urbe, a premência do conto}

Os lados do círculo, obra de autoria do gaúcho Amilcar Bettega Barbosa, publicada em 2005, foi contemplada com o prêmio Portugal Telecom 2005 de Literatura. A antologia recebeu também menção especial na premiação Casa de Las Américas, de Cuba. Merecedora de recepção positiva por parte da crítica literária, a produção em geral do escritor o tem colocado, como tem ocorrido igualmente com outros de sua geração, na posição de expoente da chamada narrativa curta da literatura brasileira contemporânea - o conto.

A importância e o crescimento desse gênero literário são notórios, o que se pode constatar apenas observando a vasta produção e a excelente qualidade não só das produções lançadas em livro como também das que circulam nos ambientes virtuais. Os autores dessas obras literárias, em número crescente em todo o país, vêm publicando contos de feição notadamente urbana, opção e prática que ganham relevo e se intensificam a partir das duas últimas décadas do século XX e dos anos do século em curso.

O conto "Verão" flagra a capital gaúcha atual, uma entre tantas outras grandes cidades brasileiras que se têm apresentado como palcos nos quais são levadas a efeito encenações e representações de um cotidiano eivado de contradições, dubiedades, paradoxos. Afinal de contas, também Porto Alegre integra o elenco das urbes inseridas nas esferas do mundo globalizado. As dimensões paradoxais e incoerentes da globalização vão desencadear a eleição do universo urbano e do imaginário de que se origina e, ao mesmo tempo, é foco desse texto, a cidade de Porto Alegre.

O conto - tomado como categoria narrativa com que também se representam as nuanças e demandas da contemporaneidade - tem sido eleito como gênero, por excelência, com o qual se realizam as recriações de aspectos da vida urbana, no caso, da cidade de Porto Alegre, bem como dos possíveis processos de desagregação de seus habitantes. Observem-se as reflexões:

[...] as formas e os modos de pertencimento, as 'verdades' daí decorrentes e os quadros dramáticos de existências anônimas imersas na capital gaúcha estariam a demandar maneiras originais e muito próprias de relato e de exposição dos pedaços de suas vidas esfaceladas. Assim, os cacos e os fragmentos urbanos captam e destacam, no universo multifacetado da fauna populacional porto-alegrense, tipos humanos cujas trajetórias entre tantas são premiadas e resgatadas como peça de ilustração dos diversos dramas diariamente teatralizados na capital gaúcha, também uma 'cidade partida'. ${ }^{1}$ (MAGALHÃES, 2014, p. 41-42).

\footnotetext{
A expressão é tomada de empréstimo da obra de Zuenir Ventura (2000).
}

A narrativa "A aventura prático-intelectual do sr. Alexandre Costa", ao recortar a zona central da capital gaúcha na atualidade, representa-a também a partir de perspectivas distanciadas dos sentidos e significados simbólicos vivenciados pela região em décadas anteriores do século passado, análise a ser feita mais adiante. O conto "Verão", centro das reflexões a serem empreendidas, enfoca a expansão de Porto Alegre para além da zona central, na medida em que focaliza um componente urbano tido como decorrência do crescimento brusco e desordenado das cidades brasileiras - a favela -, real e precário aglomerado habitacional que integra a geografia da desigualdade e da violência da capital gaúcha e de tantas outras cidades brasileiras nos dias atuais.

Não se pode deixar de observar que, em direção contrária, para além da Rua da Praia e das zonas tradicionais da cidade, estruturam-se também novos bairros, que surgem no rastro dos condomínios fechados e dos shopping centers, dois espaços notadamente contemporâneos nos quais as classes média e média alta buscam conforto, elegância, requinte, proteção.

Em relação aos condomínios fechados, convém destacar que eles crescem e ganham impulso à proporção que aumentam a violência, a periculosidade e, principalmente, o medo. São moradias que se postam como espaços que prometem, entre outros aspectos, uma suposta segurança que as ruas não mais possibilitariam e não mais disponibilizariam. Trata-se de uma tendência que vem ganhando vulto nas grandes cidades do País, ou melhor, do mundo inteiro. Os condomínios seriam os novos ghettos, igualmente espaços isolados e segregados, mas agora vivenciados como ghettos da qualidade de vida, da defesa e da confiança, ante os perigos e o medo globalizados.

O conto torna-se adequado na formatação da unicidade de ação com que se recortam e se encenam dramas humanos e sociais, instantaneamente, captados e teatralizados como componentes de um grande painel as representações do cotidiano da capital gaúcha atual. A focalização rápida que se basta e se fecha na estruturação narrativa assim se constitui, levando em conta enfoques do tempo, espaço e personagens, a partir de articulações em que são priorizados aspectos identificados com limites e reduções. Compactam-se, dessa forma, as unidades de ação, tempo, espaço e personagens, apresentadas estas últimas em número restrito. Há confluências para os sentidos de uma compressão que se constrói e se faz valer ante o propósito de representarem-se literariamente ações, enredos, cenas, cenários, personagens, subjetividades, elementos com que se flagram indivíduos num determinado tempo-espaço da urbe. Enfim, componentes estruturais irmanam-se e atuam na elaboração dos relatos que tematizam feições, facetas e segmentos da capital gaúcha nos dias atuais. 
Momentos anteriores das urbes - representadas como cartografias não tão variadas, não tão diversas e não tão múltiplas - são tidos como ápice do esplendor da cidade moderna e vão eleger sua região central como cenário da efervescência esfuziante, possibilitada também pelas transformações empreendidas pela ação modernizante. Porto Alegre, principalmente nas décadas de 50, 60 e 70, vive o brilho e a vitalidade da zona central, em especial, da Rua da Praia.

Antes de tudo, convém observar que em tal momento o centro é espaço privilegiado do encontro, da confluência, do congraçamento, enfim, do dinamismo da vida e da cidade modernas. O centro de Porto Alegre, como de resto o de toda capital brasileira naquele momento, é o local determinado no coração da urbe que assume a condição de referência tempo-espacial. A Rua da Praia do auge dos chamados "anos dourados" - homenageada e cantada num rico cancioneiro - vem a ser o elemento catalisador e irradiador das práticas, atitudes e modismos da vida moderna, principalmente entre a população mais jovem. Encravada na única centralidade (importante observar que na cidade moderna há um único centro), a Rua da Praia $^{2}$ assume caráter metafórico e metonímico, uma vez que se apresenta como porta de entrada não só do centro, mas da urbe como um todo.

É a partir dessa Rua que se irradiam os sentidos de elegância, modernidade e finesse, índices bastante ambicionados e perseguidos pela elite burguesa gaúcha. A ênfase no enfoque da Rua ilustra e realça uma prática comum naquele momento - o passeio a pé pelas ruas do centro. Pode-se afirmar que se estabelece um doce e saboroso binômio: passeio a pé e centro da cidade - um par perfeito. Nessa direção, as produções do cancioneiro se debruçam sobre aquela Rua, destacando o contato com um universo de deslumbramento fixado em canções como "Rua da praia": "[...] Rua da praia da garotinha que quer casar,/Do malandrinho que passa o dia jogando bilhar./ Rua da praia de alegres tardes domingueiras/Quando as calçadas se enfeitam de gauchinhas faceiras./Rua da praia da sede do Grêmio e Internacional/Que se embandeiram e soltam foguetes no jogo Grenal"3.

Como se observa, ganham destaque representações em que comparece a celebração da magia, encantamento e sedução das ruas. Afinal, elas por si só representam o espetáculo, na verdade, tais ruas são o espetáculo com que se envolvem, principalmente as classes média e burguesa. É lógico que a Porto Alegre daquele momento não abriga

\footnotetext{
2 A denominação Rua da Praia remonta ao passado, momento em que o Rio Guaíba chegava até o local onde havia uma praia. O Rio foi aterrado, urbanizou-se o local, que, popularmente, continua sendo chamado de Rua da Praia. O nome oficial é Rua dos Andradas.

3 A título de ilustração, são trazidos trechos da canção "Rua da Praia". Tal composição é de autoria de Alberto do Canto e a interpretação é de Alcides Gerardi.
}

apenas essas classes sociais. A focalização dessas camadas decorre da constatação de sua importância na configuração do imaginário urbano. Fora do centro e das zonas nobres, isto é, nos arrabaldes (era este o termo mais usado e não periferia, comum hoje), "[...] o povo se diverte [frequentando] as rinhas de galo" (PESAVENTO, 1999, p. 147).

As ruas dos centros das cidades brasileiras naquele momento são espaços públicos, não resta dúvida, mas vivenciadas como unidades de espaços privados. Os jovens frequentadores dos points ali situados são integrantes de uma classe social tranquilamente estruturada e gozam das prerrogativas que o pertencimento fixo e consolidado àquela esfera privilegiada lhes possibilita e lhes concede. Os espaços da Rua, como se vê, facilitam o convívio e a integração. Coexistência pacífica e harmoniosa, sim, pois nem sequer se ventila a possibilidade de aí ocorrerem interações também com outras classes sociais, no caso, com os jovens do arrabalde. É como se a presença dessa faixa populacional não se coadunasse com o compartilhamento que ali se realiza, o que remeteria a tentativa de entrosamento e até mesmo a presença desse Outro à condição de inoportunas e, talvez, de desastrosas. Diferenças e hierarquizações existem, mas não assumem o caráter de desigualdade e de exclusão radicais, desencadeadoras e detonadoras do embate social, que se faz tão incisivo e tão destruidor nos dias contemporâneos.

Em consonância com outra pegada, isto é, levando em conta sentidos bem distanciados dos expostos nas imagens elogiosas das canções, os contos esboçariam e até mesmo indiciariam a conveniência da exposição e captação de feições outras com que a capital gaúcha se apresenta hoje. Tais aspectos abrem possibilidades de caracterização e de leitura da cidade como um organismo em que convivem partes diferentes, cada uma com as próprias singularidades e que se sobrepõem no universo urbano como um todo. É no enfoque e representação desses fragmentos que o gênero conto flagra e narra o sujeito aí imerso e/ou disperso.

Neste sentido, as abordagens artísticas se despregam do intuito de recuperar apenas signos citadinos narcisistas, enaltecedores e identificados com o sonho e o desejo de uma unidade totalizadora e idealizada, como se observa nas canções ufanistas que tematizam a cidade de Porto Alegre, especialmente, sua região central. Assim, a capital gaúcha atual está a exigir não só campo para a vivência das minúcias das suas variadas vozes, mas também novas cartografias representacionais que consigam contemplar a diversidade e as demandas socioculturais em que a cidade se inscreve.

É como se as novas relações, as novas geografias, as novas cartografias urbanas estivessem a requerer geografias e cartografias narrativas à altura das contingências existenciais e das rápidas transformações em 
geral - para o bem e para o mal - com que a cidade vem se apresentando no século XXI. Aí, as vivências estão a reivindicar, a cada instante, se não suportes crítico-teóricos absolutamente novos e inéditos, pelo menos modos e formas incitantes de narrar e de relatar, enfim, procedimentos que, assumindo certo caráter de transgressão, coloquem-se no patamar dos desafios e da complexidade dos eventos urbanos.

As observações e análises permitem afirmar que não é um mero acaso a escolha do conto como gênero literário com que se realizam as representações de eventos flagrados em Porto Alegre. A cidade vem a ser o grande tablado em que se encenam vivências, experiências, realizações, alegrias, desencontros, desacertos, infelicidades de sujeitos captados no universo da sociedade gaúcha contemporânea. É o próprio Bettega Barbosa quem afirma:

[...] uma das coisas que mais me atrai no gênero conto é essa característica de estrutura que se fecha nela mesma, que se basta, seu caráter de unicidade, algo que aponta para um certo rigor, digamos, matemático. Eu queria explorar isso em termos de recurso - e ao mesmo tempo, limite - formal. Porque é a onipresente noção de limite (número de personagens, elementos do cenário, tempos narrativos e de leitura, incidentes da trama etc.) que dá ao conto o rigor formal e a economia precisa que o caracteriza. Limite, ou a ideia de limite, que, transpondo para a vidinha nossa de cada dia, a gente encontra todo o tempo e por todo o lado - para o bem e para o mal. (BETTEGA BARBOSA, 2014, p. 2).

Uma observação se faz premente: o conto "A aventura" ilustra também as relações com o centro da cidade nos dias atuais. O caráter de aura e de Meca encantadora das classes média e média alta, que emana da região nas décadas explicitadas anteriormente, arrefece, se neutraliza, na perspectiva da leitura contemporânea. As ruas onde anteriormente se situavam também locais de lazer, inclusive, à noite, hoje se apresentam desertas e abandonadas, principalmente no turno aludido, passando tais espaços e seu entorno a serem usados também como abrigos de uma população de solitários moradores de rua, vítimas, em potencial, do serial killer Alexandre Costa. Observe-se que tais alvos do psicopata não são apresentados a partir de um nome próprio ou de qualquer outra forma de identificação, que não a de moradores de rua. Aliás, a condição de errantes pressupõe o processo se não de perda ou de apagamento da identidade, pelo menos de afastamento das possibilidades de reconhecimento social daqueles indivíduos ${ }^{4}$.

\footnotetext{
4 Há um estudo sobre o conto "A aventura prático-intelectual do sr. Alexandre Costa” em: MAGALHÃES, Carlos Augusto. Cruéis travessias: violência e exclusão na Porto Alegre dos contos de Amilcar Bettega Barbosa.
}

Nas representações construídas na canção "Centro de Porto Alegre", da Sociedade Bico de Luz, a área central é vista como espaço caótico do desprazer, da confusão, e como região merecedora de restrições de caráter diverso. Nesse sentido, vai se instaurar uma significativa queda simbólica, no concernente à baixa frequência das classes referidas anteriormente. As hierarquizações fazem com que o primeiro lugar na preferência de tais classes sociais passe a ser ocupado por outros espaços, os sofisticados e confortáveis centros de comércio, lazer e serviços - os atraentes e sedutores shopping centers.

Ganham destaque e consistência nas urbes contemporâneas esses mundos fechados e independentes, que se configuram também como cidades que se plantam e se impõem no universo da urbe propriamente dita. Tal conglomerado abriga grande número de pessoas, sem dúvida, mas, diferentemente das ruas centrais da urbe moderna, o shopping center jamais assumiria sentidos metonímicos, em termos de desempenhar e assumir funções e feições inerentes àquela parte que representa o todo urbano. Assim, a natureza e o papel desses empreendimentos - como se disse, novas cidades inseridas na cidade real - não encontrariam correspondências nas relações que se estabelecem entre aquelas células urbanas - as míticas ruas centrais - e a cidade aberta e construída ao longo da história pelas mãos da própria história.

Se as hierarquizações existem desde sempre, no concernente aos desenhos e enfoques da geografia simbólica que costumam atuar nos processos de ocupação e leitura dos espaços urbanos, os dias contemporâneos têm esboçado e feito valer mapas e roteiros convincentes, eficientes, consolidados. Mais do que nunca, a eleição e a rejeição dos espaços, quer abertos quer fechados, são produtos também da ação conjugada do valor de uso e do valor de troca, sentidos tais que aqui e agora se apresentam superdimensionados, pesando, sobremaneira, o valor de natureza representacional.

Numa dimensão inversa e negativa, levando-se em conta, sobretudo o ponto de vista econômico-social, sem deixar de lado o forte aspecto simbólico, a favela vem a ser o Outro da desvalia, da inconveniência, da deselegância, da desconfiança e do desejo de distanciamento. Trata-se de um componente da morfologia físico-simbólica de muitas cidades brasileiras com o qual as camadas média e média alta da população normalmente evitam interações diretas. Preferem-se as mediações oferecidas pelas imagens dos veículos massivos, hábeis e competentes na exposição quase sempre dos aspectos espetaculares e sensacionalistas do cotidiano daquele mundo merecedor de tantas restrições, ocupando destaque os quadros de violência. Ante esse universo, esses meios de comunicação costumam atuar, como observa Beatriz Sarlo (2007), buscando inculcar e imprimir pavor e medo desmedidos. 
Por outro lado, convém lembrar que a instalação desses ajuntamentos urbanos que enfeiam e incomodam, podem e costumam se estabelecer e literalmente ganhar terreno em regiões nas quais se configuram quadros e posições de contiguidade com aquele Outro, objeto de desejo e até de consumo - o bairro chique, elegante e elitizado. Como se verá, trata-se de vizinhanças desatadas, uma vez que as densas e significativas diferenças e desigualdades se encarregam de promover o desenfeixe e o deslinde.

Porto Alegre se vê permeada por complexidades de natureza diversa, realidade que expõe suas divisões. Tais cisões se configuram, se imprimem e se fazem valer no mapeamento das estratificações com que se edificam as diversas "cidades" que se inserem na realidade da capital gaúcha atual. Se, nos primórdios da modernidade, a urbe surge e ganha sustentação e firmeza com a assunção de papéis e sentidos que realçam sua oposição ao campo, hoje ela ostenta, no próprio território, as efetivas desigualdades que tanto afastam e segregam. A esse respeito, Tânia Pellegrini (2005, p. 137) conclui:

[...] está formado o novo cenário para a revitalização do realismo e do naturalismo, agora com tintas mais sombrias, não mais divididas em 'campo' e 'cidade', como antes, mas ancoradas numa única matéria bruta, fértil e muito real: a cidade cindida, ou seja, já irremediavelmente dividida em 'centro' e 'periferia', em 'favela' e 'asfalto', em 'cidade' e 'subúrbio', em 'bairro' e 'orla', dependendo o uso desses termos da região do país.

Por fim, convém reafirmar que leituras e representações da capital gaúcha na perspectiva do aqui e do agora sugerem e demandam iniciativas abrangentes e distanciadas da voz modulada por um único tom, paradigma que, como se vê, não mais consegue estabelecer ressonâncias e se fazer ouvir, se fazer valer. Em última análise, é Porto Alegre que interliga e congrega tudo e todos sob o véu da multiplicidade e do fracionamento que cada subjetividade leva a efeito. É a cidade plural que constrói os relatos e é por eles construída.

\section{Nas tiras do texto, a violência cotidiana}

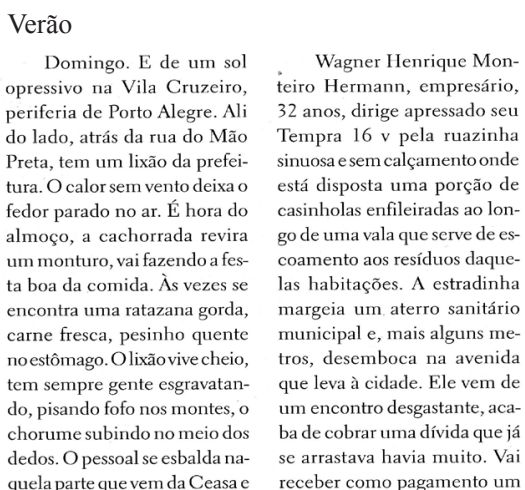

A principal dimensão híbrida [...] é resultado da interação entre a literatura e outros meios de comunicação, principalmente meios visuais, como [...] cinema, publicidade [...] e a produção da mídia em geral.

Karl Erik Schøllhammer

Mimetizando aspectos negativos da capital gaúcha contemporânea, interessa aqui mostrar quanto, principalmente, o conto "Verão" se coaduna com a proposta da "literatura do real", noção que se identifica com uma aderência a um cotidiano destrutivo, adequando-se à tradição da apresentação do real em que se nega a alteridade, possibilitando, ao contrário, terreno para o (des)encontro com a outridade, violento e fundador (SELIGMANN-SILVA, 2003). Há a encenação de um quadro paradoxal, pois consubstanciado numa fronteira em que, longe de qualquer intercâmbio construtivo, antes de tudo o que ganha terreno é a negatividade, a desavença, a desigualdade. Desenham-se a impossibilidade não só de trocas positivas como até mesmo de contatos sociais em que a outridade fosse, minimamente, contemplada e respeitada. Colocando-se de encontro a essa proposta, o conto "Verão" faz a representação de um problema social e de cenas de violência vivenciados em espaços reais de Porto Alegre - lixão/favela da Vila Cruzeiro e bairro da Bela Vista -, periferia e zona nobre, respectivamente, locus reais e simbólicos em que se insere o núcleo dramático do conto.

A narrativa tematiza situações ápices de uma rotina de exclusão e de desconfiança e, sobretudo, de impossibilidade de convívio estreito e próximo de indivíduos de classes sociais diferentes e desiguais. Não se viabilizaria o "viver juntos", conceito que propõe e encaminha uma convivência em que se priorizem, justamente, o arrefecimento e a mitigação dos distanciamentos entre os indivíduos, ou seja, seria objetivado, sobretudo, o comedimento dos efeitos e das tensões dos afastamentos que se erguem, especialmente, entre os desiguais.

Esses processos de abrandamento se formatam e se estabelecem, levando em conta, necessariamente, um "pathos da distância". Nietzsche elabora tal conceito, destacando que se trata do "[...] fosso entre um ser humano e outro, entre uma classe e outra, a multiplicidade de tipos, a vontade de ser si próprio" (NIETZSCHE, 2006, p. 87). Há que se articularem as noções de "pathos da distância" e do "viver juntos", uma vez que somente a neutralização das distâncias, isto é, certo aliviamento delas, por meio das vivências de processos nos quais se envolvam um Eu e um Outro, imbuídos ambos de propósitos de convivência, tornaria o "viver juntos" uma efetividade. Refletindo sobre a dificuldade e sobre a necessidade de moderação das polarizações e também se detendo na fantasia e no 
sonho de que um dia o compartilhamento venha a ser uma realidade, Roland Barthes (2003, p. 13) fala sobre “[...] o paradoxo, a contradição, a aporia de uma partilha das distâncias - a utopia de um socialismo das distâncias".

O "viver juntos" não é uma referência à vida de casal, isto é, duas pessoas que a partir de determinado momento resolvam se unir e dividir o cotidiano. $\mathrm{O}$ "viver juntos" vem a ser a prática do conviver - "não longe uns dos outros -, preservando cada um o seu rhythmós". Isto é, antes de qualquer outro aspecto, busca-se garantir, a cada sujeito, não só o próprio ritmo de vida, mas também suas liberdade e independência (BARTHES, 2003, p. 84).

Bastante afastados dos sentidos e noções de partilha das distâncias e da possibilidade do "viver juntos", como também longe de qualquer fantasia que esboce possibilidades de integração e de convívio, eis como se apresentam a favela da Vila Cruzeiro e o bairro da Bela Vista, mundos bem próximos, mas bastante afastados. São universos entremeados pela Avenida - signo de transição entre as "duas cidades". A partir desse traço de intermediação, ganha corpo um cotidiano em que as duas esferas apenas se suportam, desde que os contatos não se tornem próximos e as possibilidades de interações não se façam prementes.

Em caminho contrário ao "viver juntos", os dois contos se identificam com a afirmativa segundo a qual a desagregação do corpo social, a princípio, encaminha e promove o novo significado do relacionamento humano à base da indiferença. Ocorre que a indiferença é desestabilizada e a suportabilidade se rompe, se esgarça, aliás, mostra as reais feições, quando, em um conto, há uma interferência na favela e, no outro, há uma intervenção nos espaços dos moradores de rua. Desmascara-se, desse modo, uma suposta condição de convizinhança da qual poderiam emanar a tranquilidade e o pacifismo do respeito mútuo.

A dupla de contos expõe com crueldade os quadros da fratura da sociedade porto-alegrense atual. A violência e a miséria são pontos de partida para uma situação de perplexidade, ante os quadros de impasse e a ausência de propostas de encaminhamentos de soluções, o que comprova e expõe os traçados da generalizada e incisiva impotência social, diante dos desafios prementes. Ambos os textos recriam aspectos de uma violência urbana gratuita que se apresenta incontrolável e que, crescentemente, tem arremessado o cidadão a espantosos e desconcertantes estágios de neuroses, desconfianças, medos.

Observe-se que nos dois textos as cenas de violência são levadas a efeito justamente quando a ação unificada focaliza invasões dos espaços em que cada classe social instala-se e localiza-se. A presença do intruso é o elemento detonador dos conflitos e dos terríveis e chocantes desenlaces.
Por outro lado, por mais que se elejam e se busquem separações e afastamentos, inscreve-se uma pertença a que, inevitavelmente, se subjugam a cidade e a sociedade como um todo. Assim, "[...] o isolamento de cada grupo, se evita a contaminação entre grupos diferentes, não chega a impedir a aproximação que se faz de maneira violenta, pelo roubo, sequestro, mendicância etc." (BRESCIANI, 1994, p. 10) (grifo da autora).

A violência insere os dois contos numa nítida situação de "verso e reverso", conforme observação oportuna do autor da orelha da antologia, José Geraldo Couto. Nesse sentido, é como se uma classe social atingida pela hostilidade direcionada a indivíduos de seu universo, na outra narrativa realizasse o revide, vingando-se da agressão com um ataque àquele Outro que vem a ser assassinado de modo tão ou até mais violento.

O conto "Verão" ilustra os padecimentos de uma classe média que presencia, ou melhor, vivencia situações que fazem seu mundo se destroçar e desabar e, de uma hora para outra, se transformar num monte de escombros e de entulhos. Essa seria a condição a que chegam camadas médias populacionais, por conta da inesperada e absurda interação com indivíduos de categorias sociais que, a princípio, não povoariam os espaços e as relações que as classes média e média alta costumam compartilhar no seu cotidiano urbano. A desolação e a depressão de Maria Eduarda, ante o ocorrido com o noivo Wagner Henrique, ilustram a perplexidade que se articula com a não compreensão e não aceitação da brutalidade e da violência decorrentes de tão inusitado embate.

Os moradores da Vila Cruzeiro lincham Wagner Henrique Monteiro Herman, empresário, 32 anos, proprietário do Tempra $16 \mathrm{v}$ que atropela e mata o cachorro Duque. Wagner Henrique, que naquele domingo ensolarado de verão se dirige à Bela Vista, bairro onde mora a noiva Maria Eduarda de Almeida e Castro, 24 anos, recusa-se a pagar uma indenização por conta do atropelo e morte do cão de estimação do guri Bidu - o cusco $^{5}$ Duque -, "cachorro sarnoso e alegre, saltitante vira-lata sem cor definida" (BETTEGA, 2004, p. 72).

Importante observar que as personagens Wagner Henrique e Maria Eduarda são apresentadas por meio de dados que, efetivamente, as identificam e as personalizam, a começar pela explicitação do instituto civil do nome próprio e familiar. Na verdade, o que se faz é realçar sua cidadania e a classe a que pertencem. Seus trânsitos sociais e existenciais em tudo e em todos

\footnotetext{
O Dicionário de porto-alegrês, de autoria de Luís Augusto Fischer (2000, p. 85) registra: cusco - sinônimo de cachorro, largamente usado na campanha. Tenho a impressão de que, na cidade, o termo é usado pra falar mal do cachorro, como se "cusco" fosse quase um insulto. Afinando o ouvido dá para ouvir xingar cachorro de "cusco de merda". Está claro que cachorro bem tratado, de raça, etc., não se chama de cusco. V. "de renguear cusco".
} 
os aspectos se distanciam das condições em que vivem, atuam e se conduzem socialmente os moradores da Vila Cruzeiro, análise a ser feita mais adiante. Enfim, a simples caracterização dos noivos por si só já os legitima.

No conto "A aventura", a ação fixa-se no comportamento do funcionário público Alexandre Costa, como tal, homem de classe média. Ele não só se escuda na impessoalidade e na superficialidade com que podem e costumam se apresentar os contatos humanos na urbe - aspectos que o protegem e facilitam seus propósitos -, como também se aproveita da desvalia social com que são olhados e tratados os moradores de rua. Tudo concorre para que, dando vazão à própria psicopatia, o funcionário público livremente percorra as desertas ruas do entorno e do centro de Porto Alegre nas noites e madrugadas geladas, à cata de homens abandonados que ele recolhe à própria casa, onde tais desvalidos são assassinados por aquele obstinado e metódico serial killer. Como se vê, o assassino é identificado como sujeito, funcionário público, endereço fixo, cidadão reconhecido pelo componente civil - o nome próprio e o sobrenome. A condição de serial killer se agrega a esses dados, tornando-se um apêndice, um elemento a mais na vida e na identidade do cidadão Alexandre Costa. Na manhã seguinte ao assassinato e esquartejamento do homem recolhido das ruas, ele assume normalmente suas funções no órgão público em que atua como funcionário íntegro e zeloso e acima de qualquer suspeita.

Olhando-se os moradores de rua, observa-se que eles nada mais são que indivíduos errantes, maltrapilhos e perambulantes da cidade. Nada mais se conhece a respeito deles. A coisificação a que estão expostos inviabiliza qualquer possibilidade de identificação, dignidade e dignificação. Não por acaso, eles são apresentados destituídos de identificação nominal.

O processo de coletivização dos moradores da Vila Cruzeiro é outro componente importante do conto "Verão". Trata-se de um processo com que se inviabilizariam e se esconderiam as feições e individualidades das personagens. Em lugar de suas singularidades, ganha relevo a apresentação generalizada e identificada com o traço caricatural. Essa é uma prática que se faz presente em representações literárias principalmente a partir do século XIX. É o que se constata na recriação das personagens da narrativa de Émile Zola - L'assommoir -, texto em que são focalizados Paris e os habitantes do cortiço do bairro ou quarteirão de La Goutte d'Or; de Aluísio de Azevedo - O cortiço -, romance no qual se mostra a população massificada daquela habitação coletiva do Rio de Janeiro, situada em espaços onde vai crescer o bairro de Botafogo; de Jorge Amado - Suor -, romance-painel em que se foca Salvador, a partir da exposição da vida degradada e coisificada dos habitantes do casarão situado na Ladeira do Pelourinho, citando apenas alguns escritores e uma só de suas obras.

Nas três produções, coletivizam-se e caricaturam-se as personagens, processo com que se busca realçar, além da massificação, o caráter de exclusão e de carência com que o todo e a massa populacional e os locais degradados em que habitam são representados. Trata-se da "cidade do vício", espaço das mazelas, categoria tematizada por Carl Schorske (1989, p. 51) e emblemática nas primeiras representações das grandes cidades ocidentais. O conceito é cunhado pelo teórico, que empreende reflexões sobre o surgimento e crescimento da urbe no século XIX europeu.

De acordo com Bachelard (1988, p. 24, 36), “[...] a casa é um corpo de imagens que dão ao homem razões ou ilusões de estabilidade, [...] porque é o nosso canto do mundo e é, como se diz amiúde, o nosso primeiro universo". Ao contrário da imagem bachelardiana idealizada que situa "[...] a casa como um verdadeiro cosmos, um cosmos em toda a acepção do termo" (BACHELARD, 1988, p. 24), pode-se afirmar que nas três narrativas acima e, de certa forma, também no conto "Verão", a casa dos excluídos e estigmatizados assumiria outra significação semiológica: o cosmo é substituído pelo caos e os escritores vislumbrariam naquelas casas um mundo de total fracionamento e da mais absoluta fragmentação, presentes tanto no espaço físico, pequenos espaços tomados como alojamento indigno e miserável das personagens, como nelas próprias, igualmente estilhaçadas - seres mergulhados nos subterrâneos da degradação física, ética e existencial.

Nos três romances acima invocados, representam-se habitações que não abrigam e não preservam a discrição da vida íntima. Em caminho contrário, nelas imperam e se dá guarida a estágios negativos em que se flagra a degradação de personagens cuja vida particular é exposta a processos destrutivos de espetacularização. Negam-se, dessa forma, os significados sociais incorporados pela casa. Afinal, não se pode esquecer de que ela "[...] é referência não só do intimismo mais recôndito, mas também da cidadania" (MAGALHÃES, 2011, p. 233). Pensando-se na relação dos moradores da Vila Cruzeiro com o espaço habitado, torna-se oportuno afirmar que ali "[...] o espaço se confunde com a própria ordem social. [...] O espaço não existe como uma dimensão social independente e individualizada, estando sempre misturado e 'embebido' [...] em outros valores que servem para a orientação geral" (DaMATTA, 1991, p. 34).

A cidadania e a ordem social estariam interditadas no conto "Verão", negando-se, dessa forma, a descrição de Bachelard. O descompasso tipifica a inversão do idealismo, a qual se sustenta na condição de marginalização com que aquele universo físico e humano é apresentado. Em outra direção, há que se observar que o mundo da Vila 
Cruzeiro tem leis, códigos, táticas, linguagens e valores próprios. Nesse sentido, aquele universo é dotado de um sentido particular de pertença e de coletividade, valores que promovem a união e a ação conjunta, como se verá, em situações de embate com indivíduos desiguais e de classes sociais diferentes, enfim, indivíduos estrangeiros inseridos abruptamente no mundo da Vila Cruzeiro.

É o que se observa no evento de que resulta a morte de Wagner Henrique. E se orquestra a batalha que agrega tudo e todos num só propósito, ante a suposta necessidade de defesa e de vingança, iniciativas que o atropelo e a morte do cachorro desencadeiam. A reação dos moradores da Vila Cruzeiro vem a ser um ato coletivo em que a violência se impõe e se agiganta, inquestionável e automaticamente, como caminho de pólvora submerso e prestes a explodir, bastando apenas um acionamento, ínfimo que seja.

Estabelece-se uma articulação que a todos envolve. Numa ação uniforme, todos se armam com paus e pedras: Catê, Unha de Gato, Zulu, Chulé, Ovelha, as mulheres que xingam e resmungam, Mutuca - moleque barriga-d'água e retinto. Mais do que nunca, torna-se evidente o processo de reificação a que está exposta aquela população, captada e focalizada como um todo conjuntamente enfurecido. Como se vê, a precária individuação, ou melhor, a única e destrutiva forma de se reconhecer alguns deles se concretiza por meio da atribuição de apelidos ou através apenas da indicação de gênero. Enfim, todos são contemplados e agrupados a partir de uma única e decisiva qualificação - favelados. Para boa parte da cidade, os moradores da Vila Cruzeiro, caricaturalmente, são recortados no universo urbano como favelados: favela e favelados, espaço e população da desconfiança e da restrição.

Aquele modo de "viver juntos" - asfalto e favela efetivamente define e faz valer a partilha de distâncias que, longe de serem neutralizadas e arrefecidas pelas trocas positivas, produto das energias e potencialidades dos envolvidos com a convivência saudável, aqui só alimentam o ressentimento individual e social, detonadores ambos das práticas de incontida crueldade.

Na construção e feitura do conto "Verão", os sentidos de desigualdades socioeconômicas e a proximidade dos espaços físicos onde se instalam os dois universos asfalto e favela - são representados a partir de mecanismos que estão além da potência da palavra e da linguagem verbal como um todo. Isso vale dizer que os aspectos da segregação, das diferenças sociais e das dificuldades de interação definem-se também através da adoção de procedimentos técnicos, isto é, por meio de mecanismos específicos de utilização dos espaços da folha de papel em branco. Convém observar que os embates e as agressões propriamente ditas com que se envolvem os habitantes da
Vila Cruzeiro e o empresário, também são representados por meio de recursos que ultrapassam o signo linguístico, como se mostrará abaixo.

Bem mais que somente o preenchimento e a ocupação da folha, há a intenção, por meio da diagramação e da disposição das colunas, de ilustrar sentidos e a estrutura da narrativa. $\mathrm{Na}$ verdade, as duas colunas assumem caráter semiológico. A disposição gráfica esboça e indicia aspectos de uma vizinhança que, desafortunadamente, se incompatibiliza. Estabelece-se uma relação muito próxima entre o recurso visual e a temática da narrativa. Os diagramas - um identificado com o cotidiano da favela, outro voltado para o trajeto do empresário que utiliza a pista que margeia aquele aglomerado - traduzem a ironia da existência de fronteiras urbanas bem próximas, mas tão deslindadas e tão incomunicáveis.

Já o embate e a violência do enfrentamento empresário versus moradores, isto é, a interação negativa daquele frente a frente destruidor, são esboçados e representados a partir da ocupação tradicional dos espaços da folha de papel. Agora tudo se mistura! Rompem-se os limites, mesclam-se as fronteiras, digladiam-se as diferenças e, sobretudo, as desigualdades, enfim, tudo se torna nivelado e envolvido na ação e nos efeitos cruéis da violência urbana, que a todos atinge, imprimindo suas marcas. Vale dizer que a ação conjunta dos moradores da Vila Cruzeiro, os quais atuam individualmente ou em dupla, também é mostrada a partir de recursos gráficos. Com eles, se focalizam e se realçam a arma usada, os gestos esboçados e também a posição espacial de cada um na orquestração daquele ato coletivo de vingança.

Semelhante a tiras que ocupam pequenos espaços nos jornais, as duas colunas simétricas assumem funções que permitem afirmar-se o diálogo que o texto literário vem empreendendo com os meios de comunicação de massa, em termos de aproveitamento de elementos gráficos, sensoriais, imagéticos, enfim, recursos de que a representação literária também se beneficiaria. Essa prática e esse experimentalismo não passam despercebidos pela crítica: "[...] a ficção recebe na carne mais sensível o impacto do boom jornalístico moderno, do espantoso incremento de revistas e pequenos semanários, da propaganda, da televisão" (CANDIDO, 1987, p. 209).

Olhando a disposição gráfica e as feições assumidas com a ocupação da folha em branco, constata-se certa similitude entre o conto "Verão" e as matérias jornalísticas que preenchem espaços que se assemelham a tiras nas quais se relatam fatos, notícias diversas ou até mesmo uma crônica literária diária ou semanal. A linearidade com que se faz o relato dos fatos e a clareza e a objetividade com que se apresenta a linguagem também contribuem para a percepção de certa semelhança que se desenharia entre o conto e os informes dos noticiosos de circulação diária. 
Trata-se de produções jornalísticas bastante consumidas por ávidos e ansiosos leitores.

A disposição gráfica encaminharia entrecruzamentos de discursos de que brotaria certo caráter de transformação em que há misturas. Schøllhammer $(2009$, p. 31) observa que "[...] a principal dimensão híbrida, na prosa [...] é resultado da interação entre a literatura e outros meios de comunicação, principalmente meios visuais, como fotografia, cinema, publicidade, vídeo e a produção da mídia em geral". Comentando aspectos identificados com acertos e êxitos, bem como certa configuração semiótica que a disposição e a forma das duas colunas desempenhariam e assumiriam, é o autor do conto quem afirma:

[...] é um conto que não tem muita complexidade, tirando a forma com que ele é apresentado. [...] Ele acabou entrando justamente pela forma. [...] Acho que consigo produzir ali, através de elementos que dizem respeito à maneira de construir o relato, de apresentá-lo, de dispô-lo na página, uma espécie de "imantação" do texto, ou seja, todos os elementos do texto se orientam na direção do que a narrativa conta, a maneira como o texto se apresenta também conta a história que suas linhas contam. (BETTEGA BARBOSA, 2014, p. 3).

A violência vem a se constituir em uma das mais terríveis fissuras da sociedade brasileira atual, não resta dúvida. Indiscutivelmente, ela passa a ocupar a posição de protagonista nas obras artísticas, haja vista sua presença reiterada em tantas produções contemporâneas, especialmente nas representações literárias e cinematográficas.

Ainda em relação ao conto em estudo, pode-se dizer que o primeiro contato do leitor com o título "Verão", falando-se de Porto Alegre, desencadeia certa curiosidade e até mesmo um inquietante estranhamento. Sem que se dê conta a princípio, aos poucos se vai observando que o sentimento de estranheza provém do fato de que aquele signo estaria borrando e rasurando um clichê histórica e nacionalmente sedimentado. Normalmente, referências ao Rio Grande do Sul e a Porto Alegre, de imediato, entre outros aspectos como a preponderante ascendência europeia da população, remete à especificidade climática identificada com o frio. Toma-se a Região Sul, principalmente o Rio Grande do Sul, como símbolo do frio do Brasil. O frio seria assim uma metáfora para o gaúcho. O clichê é tão forte que chega a criar uma caracterização, de certo modo, identitária que se articularia com uma sensibilidade específica irmanada com uma "estética do frio". Tal qualificação e maneira de ser se afastariam da identidade e do modo de vida do restante do Brasil e do povo brasileiro como um todo. Refletindo sobre esses aspectos, Ramil (1992, p. 263) questiona e elabora conclusões:
[...] qual é a minha tradição? A tradição brasileira é minha? É natural que eu atue com ela e a partir dela? Mas tenho diferenças que me distanciam da 'comunhão tropical'? Tenho mais forte a tradição de um 'país frio', a tradição de um 'país deslocado' do Brasil, ao mesmo tempo tão próximo do Uruguai e da Argentina? É natural que eu atue, com e a partir dessa tradição 'fria'? Sim! Devo fazer valer este sentimento de 'dupla personalidade', devo querer o máximo desta "dupla cidadania" fazer dela fonte de criação e não fonte de diluição da minha capacidade criadora. Pensando o 'frio' como metáfora amplamente definidora do gaúcho, acho que uma concepção 'fria' tem muito o que fazer com uma concepção 'quente'. Estou pensando em uma 'Estética do frio'.

A leitura do conto logicamente esclarece o título e aplaca a curiosidade e o pasmo, chegando não só a esmaecer as leituras clicherizadas do frio como imagem que remete à Região Sul do País, mas também a neutralizar as especificidades do conceito e sentido da "estética do frio".

A capital gaúcha, flagrada agora num dia de verão, iguala-se às outras grandes urbes brasileiras, no concernente à dimensão da brutal violência que nivela e uniformiza as grandes cidades do País em qualquer latitude, em qualquer longitude, o que vale dizer, de norte a sul, de leste a oeste. Assim, também Porto Alegre se sente e se vê mergulhada nas sombras da perplexidade e do medo, ante o enfrentamento do nonsense do abrasante e cruel "verão" da violência avassaladora.

\section{Referências}

BACHELARD, Gaston. A poética do espaço. Tradução de Antonio de Pádua Danesi. São Paulo: Martins Fontes, 1988.

BARBOSA, Amilcar Bettega. Matemática do conto. Entrevista concedida a Carlos Eduardo Ortolan Miranda. Disponível em: $<$ http://www.revistatropico. com.br/tropico/html/textos/2725,1. shl>. Acesso em 31 go. 2014.

BARBOSA, Amilcar Bettega. Os lados do círculo. São Paulo: Companhia das Letras, 2004.

BARTHES, Roland. Como viver junto: simulações romanescas de alguns espaços cotidianos. Cursos e seminários no Collège de France, 1976-1977. Tradução de Leyla Perrone-Moisés. 2. ed. São Paulo: Martins Fontes, 2013.

BRESCIANI, Maria Stella. A cidade das multidões, a cidade aterrorizada. In: PECHMAN, Robert Mose (Org.). Olhares sobre a cidade. Rio de Janeiro: UFRJ, 1994, p. 9-42.

CANDIDO, Antonio. A nova narrativa. A educação pela noite e outros ensaios. São Paulo: Ática, 1987. p. 199-215.

DAMATTA, Roberto. A casa \& a rua: espaço, cidadania, mulher e morte no Brasil. Rio de Janeiro: Guanabara Koogan, 1991.

FISCHER, Luís Augusto. Dicionário de porto-alegrês. Porto Alegre: Artes e Ofício, 2000. 
MAGAlHÃES, Carlos Augusto. Cena moderna: a cidade da Bahia no romance de Jorge Amado. Salvador: Quarteto, 2011.

MAGALHÃES, Carlos Augusto. Cruéis travessias: violência e exclusão na Porto Alegre dos contos de Amilcar Bettega Barbosa. In: CAMARGO, Flávio Pereira; CARDOSO, João Batista (Org.). Estudos de ficção brasileira contemporânea: produção, recepção e crítica. São Paulo: Fonte Editorial, 2014. p. 31-62.

NIETZSCHE, Friedrich. Crepúsculo dos ídolos - ou, Como se filosofa com o martelo. Tradução de Paulo César de Souza. São Paulo: Companhia das Letras, 2006.

PELEGRINI, Tânia. As vozes da violência na cultura brasileira contemporânea. Crítica Marxista, Rio de Janeiro, Revan, n. 21, p. 132-153, 2005.

PESAVENTO, Sandra Jatahy. Memória Porto Alegre: espaços e vivências. 2. ed. Porto Alegre: UFRGS, 1999.

RAMIL, Vítor. A estética do frio. In: GONZAGA, Sergius; FISCHER, Luís Augusto (Coord.). Nós, os gaúchos. Porto Alegre: UFRGS, 1992. p. 262-270.
SARLO, Beatriz. Tempo presente: cultura da memória e guinada subjetiva. Tradução de Rosa Freire d'Aguiar. São Paulo: Companhia das Letras; Belo Horizonte: UFMG, 2007.

SCHØLLHAMMER, Karl Erik. Ficção brasileira contemporânea. Rio de Janeiro: Civilização Brasileira, 2009.

SCHORSKE, Carl. A cidade segundo o pensamento europeu: de Voltaire a Spengler. Tradução de Hélio Alan Saltorelli. Espaço \& Debates: imagens e representação da cidade, Curitiba, v. 9, n. 27, p. 47-57, 1989.

SELIGMANN-SILVA, Márcio. Violência, encarceramento, (in)justiça: memórias de histórias reais das prisões paulistas. Revista de Letras, São Paulo, v. 43, n. 2, p. 29-47, jul./dez. 2003.

VENTURA, Zuenir. Cidade partida. São Paulo: Companhia das Letras, 2000.

Recebido: 29 de outubro de 2014 Aprovado: 25 de novembro de 2015 Contato: carlosmagal@terra.com.br 